[Vicino Oriente XXIII (2019), pp. 185-206]

\title{
THE BIRD-SHAPED FINIAL ON ISLAMIC ROYAL PARASOLS: A GHAZNAVID OR FATIMID INNOVATION?
}

\author{
Valentina Laviola - University of Naples "L'Orientale"
}

This paper aims at investigating when and why the bird-shaped finial made its appearance on Islamic parasols through the analysis of written sources and miniature paintings. Evidence attest to the trans-regional and diachronic use of the parasol as a royal insignia whose meaning and value grew wider to symbolise the seat of government, was it the royal tent, palace or throne.

Keywords: parasol; Islamic royal insignia; Iran; Ghaznavids; Fatimids

\section{THE LONG-LASTING TRADITION OF THE PARASOL}

The parasol, a device to provide shadow repairing from the sun (or snow), is alternatively referred to as mizalla, shamsa ${ }^{1}$ or shamsiyya in the Arabic-speaking context, ${ }^{2}$ and chatr $^{3}$ in the Persian-speaking areas. It is attested as a royal insignia in almost every Islamic dynasty, but the Islamic period was not at all its starting point. In fact, the history of the parasol is far more ancient. The device has been in use throughout a very long period extending from Antiquity to the Modern Age, and in different cultural areas.

Evidence come from Egypt, ${ }^{4}$ Assyria, Achaemenid and Sasanian Persia, ${ }^{5}$ where the parasol is usually held by an attendant standing behind the figure of the king as an attribute of royalty; ${ }^{6}$ a further spread concerned Asia from China ${ }^{7}$ to the west. ${ }^{8}$

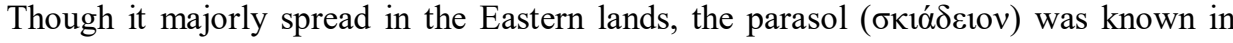
Late Archaic and Classical Athens as well. Greece seems to be the only territory where it was not reserved to men. ${ }^{9}$ The depiction of a parasol-bearer attending someone other than a

In some Islamic contexts such as the Abbasid and Fatimid courts, the term shamsa might indicate a crown suspended above the caliph's head, not to be confused with the parasol (see Halm 1995; 1997).

2 Bosworth 1993, 191-192.

3 The Persian term chatr is borrowed from the Sanskrit, thus attesting a very ancient origin of the device and alluding to its use in the Indian context. Monneret de Villard $(1968,270)$ reports that, before the Hellenism exerted its influence on the Indian art, Buddha was represented through symbols: among these, there were the parasol and the throne. From the term chatr derive the variations shitr or jitr, demonstrating that the oriental origin of the device was still perceived (see Korn 2012, 149). In addition, the term tayyāra indicated the sunshade placed above the throne of Rustam in Tabarī (d. 923; see Friedmann 1992, 82).

4 The parasol was known in Egypt since the $3^{\text {rd }}$ millennium BCE (McDonald 1999; cf. also Miller 1992, 93).

5 See Muscarella 2013, 817-824, with related bibliography. About the parasol portrayed in the Sasanian reliefs of Ṭāq-i Bustān, see Ghirshman 1962, fig. 237.

6 Sims 1992, 77.

7 A figure wearing a tiara and carrying a parasol (chattra) is depicted on a stone pedestal from the Indian Museum of Calcutta (inv. no. A 25157 B.G. 51): the scene probably refers to a divine episode (see Bénist 1981-1982, 212, fig. 3). A fragmentary parasol of Han production has been found; both royal and devotiona uses are attested in the Buddhist context, and recalled by the stupas as well (for both information see Andrews 1993, 192).

8 Two parasols are portrayed in a religious scene on a coin struck by Caracalla (r. 211-217; see Andrews 1993, 192).

9 The parasol is depicted as part of the feminine equipment in $4^{\text {th }}$-century funerary iconography (a maid holds the parasol above the seated lady; see Miller 1992, 92), $6^{\text {th }}$-century vases (Miller 1992, 95) and in the divine

ISSN 0393-0300

e-ISSN 2532-5159

Rivista Open Access 
king in Late Archaic Lycia might be explained as a custom resulted from the cultural influence of Persia. ${ }^{10}$

There is no reference to the parasol under the Umayyads; conversely, its use is attested in the Umayyad caliphate of al-Andalus ${ }^{11}$ and under the Normans ${ }^{12}$ that is to say in the western extremities of the Islamic and Islamic influenced territories.

\section{THE ROYAL PARASOL AND ITS BIRD-SHAPED FINIAL IN THE IRANIAN LANDS DURING THE ISLAMIC PERIOD}

The presence of a bird-shaped finial on top of royal parasols is confirmed for the first time by historical sources during the Ghaznavid period. Fakhr-i Mudabbir (d. 1236) in his $\bar{A} d \bar{a} b$ al-hâarb wa 'l-shajā 'a writes about the finial topping Sultan Mas 'ūd III's parasol:

«In the year 503 [1109] the Sultān-i Karīm 'Alā’ud-Dawla Mas 'ūd son of Raḍī Ibrāhīm (May God purify their dust!) marched toward Bust. An exquisite, precious and unique pearl fell down from the beak of the falcon surmounting the Sultan's umbrella». ${ }^{13}$

This passage provides an information that let the reader to imagine the parasol's finial as a true jewel. It is reminiscent of the Sasanian crown worn by Hormuzd II (r. 303-309) that featured not only the typical spread wings but a complete bird of prey, portrayed by the profile, holding in its beak a drop-shaped element (possibly a pearl). ${ }^{14}$ Thus, the presence of a jewelled falcon on top of the royal insignia - attested also under Ibrāhīm (r. 1059-1099) - $^{15}$ may have been inspired to the ancient Iranian tradition. ${ }^{16}$

context on the Parthenon eastern frieze (Eros holds the parasol above Aphrodite; Miller 1992, 103); in fact, the parasol was a mark of social and political distinction for Athenian ladies since it was reserved to citizens Few exceptions are attested in the Islamic context. As narrated by Clavijo (ambassador to the Tīmūr's court), in 1404 Tīmūr's first wife Sarāy-Mulk Khātūn made her entry into the court under a white silk paraso (Andrews 1993, 193). A painting (probably Samarakand, $15^{\text {th }}$ century, Istanbul, Saray1 Topkap1 Library, Ms. H. 2153, fol. 165r, cf. Haase 1981, fig. 250) illustrates a scene probably drawn from the history of Solomon transposed into a Timurid setting: a large parasol, held by an angel, shadows a couple carried inside a platform by jinns. Moreover, Shīrīn appears shadowed by a parasol in "Shirin on her way to Farhad", Nizāāmī's Khamsa, Herat, 1491, Moscow, The Museum of Oriental Art, Ms. 1659 II, fol. 66r, cf. Karpova 1981, not numbered ill. See also fn. 36 about the parasol used by the royal family among the Qarakhanids.

$10 \quad$ Miller 1992, 94.

11 Flood - Necipoğlu eds. 2017, 242. On portable canopies see Chalmeta 1993.

12 Byzantines and Fatimids represented the royal prototypes Roger II of Sicily (r. 1130-1154) looked at. Depictions in the Cappella Palatina in Palermo show a set of insignia of sovereignty: a variety of headgear, the parasol, which always matched the fabric of the caliph's costume, a sceptre, sword and shield (see Tolar 2011, 32). A parasol (al-mizalla) would have been sent to the Norman kings as a gift from the Fatimid caliph (see Flood - Necipoğlu eds. 2017, 379).

13 Shafi 1938, 200 (emphasis added)

14 See Fontana 2012, 95; cf. Erdmann 1951, 99, fn. 47, and also fn. 38, fig. 18; Göbl 1971, pl. 5:14. See also Halm 1995, 131.

15 Bosworth 1963, 280, fn. 23.

16 Such a continuity of customs can be traced in the use of a jewelled, suspended crown in vogue among the Sasanian kings as well as under the Abbasid and Fatimid caliphs. See above, fn. 1. Moreover, on the drachms 
The court-poet Sayyid Hasan (d. 1161) confirms that the parasols of Mas 'ūd III and his son Bahrām Shāh (r. 1117-1150; 1152-1157) featured a falcon on their top:

مبارك اوج تخت او فلى را بر كنار آرد خجسته باز جتراو جهان رازير بردارد

«Blessed be the top of his throne that brings the firmament closer

Fortunate be the falcon of his parasol that raises the world below». ${ }^{18}$

Miniatures produced from the mid- $14^{\text {th }}$ century onward show episodes related to the Ghaznavid history which can be held as a demonstration of the custom. The bird-shaped finial appears two times in a Shāhnäma's miniature (Iran, 1446) on top of both the throne where Sultan Mahmūd (r. 998-1030) is seated and the wide parasol above him (fig. 1). ${ }^{19}$ It must have been a well-established role to justify such a pleonastic repetition.

A further detail concerning the colour of the Ghaznavid parasol comes from the Tärīkh-i Mas 'ì $\bar{l} \bar{\imath}$ by Bayhaqī (d. 1077), who reports an episode occurred in the aftermath of the defeat of Dandānqān (1040), ${ }^{20}$ when the Sultan had to flee to Ghazni leaving everything behind:

«Before the Amir left Rebāṭ-e Karvān, a trusty messenger arrived from the castellan $\mathrm{Bu}$ 'Ali. He brought two black ceremonial parasols, a black banner and short spears, all placed in a black satin brocade bag, an elephant litter and a mule litter, together with other pieces of equipment, since all these insignia of royalty had been lost (i.e. in the flight from the battlefield)». ${ }^{21}$

A Safavid miniature could confirm the choice of a dark colour: it illustrates a convivial meeting of Firdowsī with three among the Ghaznavid court's poets, 'Unșurī, Farrukhī and 'Asjudī; on the background, there is a man carrying a closed black parasol (fig. 2). ${ }^{22}$

Episodes mentioning the parasol without providing any specific detail about its finial abound. The chatr-dār was one of the highest tasks a ghulam could attain to, along with the standard bearer, the master of the wardrobe, and the armour-bearer, ${ }^{23}$ and still before the

issued by the Persian king Phraates IV (r. 40-3 BCE) was depicted a falcon holding a diadem in its beak (see Daryaee - Malekzadeh 2018, 247).

17 Khan 1949, 83.

18 I wish to thank Viola Allegranzi for translating from Persian.

19 The majority of miniatures mentioned as examples in this paper are drawn from this manuscript and the Rashīd al-Dīn's Jāmi al-Tawārīkh, Herat, 1430 ca., Bibliothèque nationale de France, Supplément persan 1113 , since they are among the oldest ones attesting bird-shaped finials and fully accessible online.

20 The defeat of Dandānqān cost the Ghaznavids the loss of Khurasan in favour of the Seljuqs.

21 Bosworth 2011, II, 338 (emphasis added).

22 The miniature belongs to a Shāhnāma's manuscript started under Shāh Ismā īl (r. 1501-1524) and completed in 1535 under Shāh Ṭahmāsp (r. 1524-1576), thus known as the "Shāhnāma of Shāh Ṭahmāsp". It is currently preserved in Toronto, Aga Khan Museum, Ms. AKM 156, fol. 7r. The isolated figure standing on the right and dressed in yellow might represent Sultan Mạ̣mūd; he seems to wear a falconer's glove. The poet Mas 'ūd-i Sa 'd (d. 1121-2) mentions the black canopy of Bahrām Shāh as well (see Khan 1949, 82-83).

23 Bosworth 1963, 105. On the occurrence of the parasol already under the Samanids, cf. below and fn. 28 
prince Mawdūd ascended the throne, his ghulāms were entrusted to carry the ceremonial parasol. $^{24}$

With regard to the warfare context, the already mentioned $\bar{A} d \bar{a} b$ al-hārb wa'l-shajā' $a$ (late $12^{\text {th }}$-early $13^{\text {th }}$ century) by Fakhr-i Mudabbir narrates the fight between Bahrām Shāh and Muhammad-i Bā Halīm, who revolted against him:

«The drums were beaten and the army ranged itself in battel order. The ungrateful Mohammad-i-Bā Halīm spread his umbrella and delivered an attack in the centre». ${ }^{25}$

During the attack led to Lahore, the «chatar» (umbrella) is the insignia held above «the infidel pretender» riding a horse on the battlefield. ${ }^{26}$ Both these passages attest that the parasol was used as an official signal to set the battle starting and that its value of royal insignia was recognised as such beyond the Islamic field. Moreover, during the reign of Mas'ūd III, carrying off the enemy's standard or chatr on the battlefield was regarded among the actions that might earn a special reward in the plunder's share. ${ }^{27}$

The chatr must have entered the Ghaznavid court along with the administrative and royal protocols acquired from the Samanids, among those it is attested in the $10^{\text {th }}$ century. ${ }^{28}$ The custom spread in the Iranian lands so that, in the aftermath of 1092, the chatr had become such a highly symbolical device in the Seljuq protocol that a son of Nizām al-Mulk gave Sultan Berkyaruq (r. 1092-1105) «the sarāparda and the royal umbrella which are royal insignia (ālāt-i salțanat az sarāparda wa chatr)» in the attempt of obtaining the vizierate. $^{29}$

The Seljuq prince Qāwurd (d. 1073) tried to act as an independent ruler by adopting «the royal insignia of a parasol (chatr), stamping on documents a tughra or official emblem $[\ldots]$ and assuming the regal titles». ${ }^{30}$

Among the episodes most frequently illustrated in miniatures there is the meeting of the Seljuq Sanjar (r. 1097-1118) with an old woman: the Sultan is always portrayed mounting a horse and shadowed by a large parasol, which is sometimes topped by a golden bird-shaped finial (fig. 3). ${ }^{31}$ The story is drawn from the first poem of Nizāāī’s Khamsa, the Makhzan

Bosworth 1977, 12.

Shafi 1938, 226 (emphasis added).

Shafi 1938, 214

27 Bosworth 1963, 126. The loss of insignia corresponded to a loss of power: «the capture, appropriation, or usurpation of a royal standard or parasol could mean defeat or rebellion». To protect the royal insignia was a point of honour on the battlefield; otherwise, the king would be deprived of the visible signs of his authority (see Flood 2009, 122).

28 Bosworth 1963, fn. 23; see also Andrews 1993, 193.

29 See Durand-Guédy 2013, 168.

30 Bosworth 1968, 88

31 For other miniatures illustrating this episode and featuring parasols fitted with bird finials, see, for instance, other paintings from manuscripts of Nizāāmı̄’s Khamsa: Herat, $15^{\text {th }}$ century, Staatsbibliothek zu Berlin, Diez A fol. 7, fol. 19r (cf. SBB website); Iran, 1529, Los Angeles County Museum of Art, the Edwin Binney, 3rd, Collection of Turkish Art, Ms. M.85.237.16 (cf. LACM website); Tabriz, 1539-43, London, British Library, Ms. Or. 2265, fol. 18r (cf. Sims - Marshak - Grube 2002, fig. 127). The episode is portrayed in other miniatures, which do not include the bird-shaped finial (cf. Minissale 2000, 61, 107 and followings.). 
al-asrār (the Treasury of Secrets) but, curiously, Nizāmī makes no mention of the parasol in his text, ${ }^{32}$ while many miniatures include this detail. ${ }^{33}$ A possible explanation could be found in a contamination derived from another episode narrated in Nizāmī's Dìwān about the Prophet Muhammad and the [Turk] king of the Ka'ba, who appears under a black parasol:
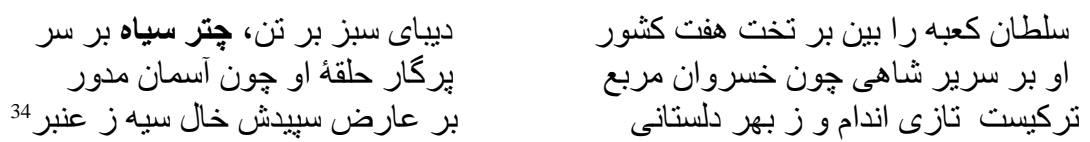

«Look at the Sultan of Ka'ba, on the throne of the seven lands Green silk on his body, a black parasol (čatr-i siyāh) on his head /

$\mathrm{He}$, sitting on the royal throne, cross-legged like the kings

The compass of his ring circular like the sky /

It's a beloved (Turk) with an Arab body, due to snatching hearts

On his white face, there is a black mole of ambergris». ${ }^{35}$

As seen above, black was the colour of the Ghaznavid insignia. ${ }^{36}$ Since the Seljuqs as much as the Ghaznavids were Sultans of Turkic origin, the black parasol may have been inserted in miniatures to connote the Turkic lineage of Sultan Sanjar. It would thus represent a figurative link between the two dynasties.

See Dārāb 1945, 167-169.

Cf. above, fn. 31

Nafisī 1959, 232

5 The first and third lines are taken from Lornejad - Doostzadeh 2012, 116, with few corrections by the author. The second line has been translated by Viola Allegranzi.

36 The parasol's colour was probably a communicating detail. Ayyubids and Mamluks used yellow parasols (see Andrews 1993, 193). References in the Persian literature provide images of great impact: the golden parasol, chatr-i zarrin, was intended as a metaphor of the sun, as well as the chatr-i simin, as a metaphor of the full moon with its silvery colour, and the chatr-i 'ambarin means the darkness of night. Kings of Persian culture were certainly well aware of such poetical imageries and probably considered them in choosing their parasols fabric (see Sims 1992, 78). The Seljuq Tughril Beg (r. 1037-1063) is known to have entered Nishapur under a red parasol after his conquest. Red tents and standards were in use among the Qarakhanids as well (see Andrews 1993, 193; Durand-Guédy 2013, 171). Among the Qarakhanids a black silk, curved parasol was part of the 'alämät al-harb, emblems of war on the battlefield and the single emblem of rank attributed to the chief minister, while the orange one was reserved for the sovereign and his family. The Khitan parasol was red with a gilt finial. The Seljuq of Rum Ghiyath al-Dīn Kay Khusraws II (r. 1237-1246) changed the colour from black to blue to mark his opposition against the Abbasids. Chingis Khān had a yellow and red parasol; red was that of the Ilkhans. Tīmūr (r. 1370-1405) is portrayed in a miniature entering Samarkand under a parasol (from a copy of Sharaf al-Dīn 'Alī Yazdī’s Zafarnāma, Shiraz, 1434-36 ca., Washington D.C., Freer Gallery of Art, inv. no. 48.18, cf. Gray 1961, 97) of dark red brocade decorated with small, gold motifs. A Safavid parasol with arabesque brocade, sometimes a fringe, maybe a gilded bird on top, is depicted in painted outdoor scenes (for all these informations see Andrews 1993, 193). Nevertheless, the parasols portrayed in miniatures not always respect the historical colours. 
According to Ibn al-Athīr (d. 1233), the Seljuq Sulaymān Shāh (the nephew of Malik Shāh, r. 1159-1160) entered Baghdad under a parasol to pay visit to the Abbasid caliph. ${ }^{37}$ The same historian reports that the Ghurid 'Alā'l-dīn Husayn Jahānsūz (r. 1141-1169) adopted some of the royal features in use among the Ghaznavids and the Seljuqs, such as the title of al-sultān al-mu 'azzam and the ceremonial parasol (chatr). ${ }^{38}$

Later on, the Ilkhanid Jalāl al-Dīn (r. 1412) surrounded the encampment of a rebellious relative, who recognised him as the Sultan thanks to the parasol held over his head. ${ }^{39}$

During the Timurid and Safavid periods many miniatures illustrating scenes drawn from history and literature, related to the Iranian epic as to coeval events, were produced. Some of them show parasols provided with a bird-shaped finial. ${ }^{40}$

\section{THE ROYAL PARASOL AND ITS BIRD-SHAPED FINIAL IN ISLAMIC EGYPT}

The use of the parasol is testified in Fatimid Egypt, but the presence of a bird-shaped finial on its top is attested only during the reign of the Fatimids' successors. Moreover, while the use of the parasol in the Iranian Islamic lands is attested by both written sources and images, its tradition in the Islamic Mediterranean emerges merely by historical sources.

As well as under the Ghaznavids, at the Fatimids carrying the parasol corresponded to a high rank. In the $11^{\text {th }}$ century, though Slavs became less prominent in the army they nevertheless continued to be the favoured ones for such task. The șăhib al-mizalla occupied the fourth level in the administrative-military hierarchy after the vizier, the head chamberlain or șāhib al-bāb, and the commander-in-chief or isfahsālār ${ }^{41}$

Gold seems to have been the favourite colour for parasols: in 990, al- 'Azīz (r. 975-996) rode to the Azhar Mosque under a mizâlla mudhahhaba, ${ }^{42}$ while the parasol used by alZāhir (r. 1021-1036) in 1024 had heavy gold fringes. ${ }^{43}$

Numerous references relate the role of the parasol to the royal lineage. The amir 'Abd Allāh, son of the caliph al-Mu'izz (r. 953-975) returned to Cairo in 973-4 after the successful fight against the Qaramatians. He made his entrance shaded by a parasol (mizalla), which was «ordinarily a caliphal prerogative». Al-Mu izz received him sitting under a dome (qubba) over the gate of the palace. ${ }^{44}$ The amir is granted with a great honour as a recognition of his military merit; still the caliph stands higher than anyone else does.

\footnotetext{
Richards 2016, 77-78.

Bosworth 1965, 1100 .

Boyle 1968, 326.

A bird finial appears on top of a closed parasol in a scene drawn from Nizāmī’s Khamsa portraying "Khusraw arriving at the palace of Shīrīn" in a manuscript from Baghdad, 1386-88, London, British Library, Ms. Or. 13297, fol. 80r (cf. Canby 1993, 43, fig. 23) and another one from Tabriz, 1410, Washington D.C., Freer Gallery of Art, inv. no. 31.36 (cf. Grube 1995, fig. 67). See also "The execution of Farāmurz in front of Bahman", Bahmannāma, Shiraz (?), 1397, Ms. Or. 2780, fol. 163v, London, British Library, cf. Stchoukine 1954, pl. XV. From Rashīd al-Dīn's Jāmi al-Tawārīkh, Herat, 1430, Paris, Bibliothèque nationale de France, Supplément persan 1113, fols. 177r and 217v (cf. BnF website). For a bird-shaped finial on a canopy see from the same manuscript "The funeral of Ghāzān", fol. 245v (cf. BnF website).

41 Bosworth 1995, 879.

42 Sanders 1994, 48.

43 Sanders 1994, 26

44 Sanders 1994, 22.
} 
The qubba - a fixed structure located in an upper position - answers to the mizalla granted to his son, so that the hierarchic order is maintained through its visible symbols.

Moreover, when al-Mu'izz died the event was only revealed as his successor al- 'Azīz rode in procession to the mosque for the ' $\bar{l} d$ al-nahr under the parasol and then pronounced the khutba in his own name: thus, the parasol was such strong a symbol to equalise the Friday sermon, traditionally considered the way through which the ruler demonstrates his power along with the coinage (sikka). ${ }^{45}$

Another episode attests that the parasol was carried over al-'Azīz's heir apparent Manșūr during the Ramaḍān procession in 993. On that occasion, even the caliph rode without its shade: the impression made on the public must have been great, the caliph renounced to his own insignia in favour of his successor, so to show him officially as the next ruler. 46

A further interesting aspect emerges from the sources: the parasol was only employed in outdoor settings during processions for festivities and celebrations and it was never carried within the palace walls. ${ }^{47}$ By the analysis of the sources, the same can be said for the Ghaznavids; and after all, this was the custom in the Antiquity. ${ }^{48}$ According to Sanders, this choice in the Fatimid context can be explained by the identification of the parasol with the palace itself. ${ }^{49}$ The parasol thus becomes a sort of synopsis of the royal palace that can follow the king when he is outdoor. The relation between the qubba and the parasol highlighted in the episode about the caliph al- $\mathrm{Mu}^{\mathrm{i}} \mathrm{izz}^{50}$ is revealing: the two highest ranks in the reign are marked by two elements (qubba and parasol) that become interchangeable.

Most references to the Fatimid court concern official ceremonies of various kind, and in particular those linked to the Nile occurring twice a year: perfuming the Nilometer and cutting the canal when the Nile reached sixteen cubits. The latter occurred in 1122: «the caliph emerged from the Gold Gate [...] The parasol was unfurled and the caliph [al-Āmir] began the procession while the Qur' an was being recited». ${ }^{51}$

Ibn al-Tuwayr (d. 1220) describes the preparation that preceded the celebration of the New Year. ${ }^{52}$ The royal insignia were usually kept in the palace treasuries under the responsibility of high officials; the parasol was selected together with the caliph's outfit so that the elements match one another. ${ }^{53}$ «After the caliph mounted his horse [...] the three

Sanders 1994, 25-26.

46 Sanders 1994, 25-26.

47 «The parasol had been opened to the caliph's right as he exited from the Festival Gate» proceeding to the mușallā (see Sanders 1994, 77).

48 Assyrian, Achaemenid and Sasanian kings portrayed under a parasol invariably appear in outdoor scenes. See above and fn. 5, and cf. also below and fn. 61 .

49 Sanders 1994, 26.

50 See above and fn. 44

51 Sanders 1994, 108.

52 Ibn al-Tuwayr does not specify the caliph's name. Taking into account his life's extent, it should be one of the last four Fatimid caliphs: al-Hāfiz (r. 1130-1149), al-Zāâfir (r. 1149-1154), al-Fā' iz (r. 1154-1160), or al-' 'Ạ̣iḍ (r. 1160-1171).

53 In his list of the royal instruments («On Royal Instruments Especially for Grand Processions») al-Qalqashandi (d. 1418) confirms that the parasol (mizalla) always matched the fabric of the caliph's costume (see Sanders 1994, 25, who nevertheless denounces that al-Qalqashandī's list reflects Mamluk categories which appear anachronistic related to the Fatimids). 
main insignia, the parasol, sword, and inkstand, were brought out and given to their porters. The porter unfurled the parasol with the assistance of four Șaqlabī eunuchs, and he placed it firmly in the stirrup of his horse, holding the pole with a bar over his head». ${ }^{54}$ This passage describes the high care devoted to the parasol and proves that it was as important as betterknown insignia. To this respect, Sanders stresses: «all things associated with the caliph were accorded the same reverence as the caliph himself». 55

The presence of a bird-shaped finial is attested only under the Ayyubids and Mamluks by al-Qalqashandī who includes the parasol in his chapter entitled «On the protocols and instruments of royalty»:

«called al-jitr, described as a yellow silk dome brocaded with gold that has a gold-plated silver bird at its apex. It is carried above the sultan's head during [the processions of] the two feasts. This item was carried over from the Fatimid era». ${ }^{56}$

He also reports that the Mamluk dār al-tirāz produced parasols topped by a bird-shaped jewel. The device, shaped on a Fatimid prototype, became known as al-qubba wa'l-tayr, the dome and the bird.

The custom spread southward: in his travel's report Ibn Battūṭa (d. 1368-9) attests the persistence of the parasol in the African region during the mid- $14^{\text {th }}$ century as a reminiscence of the Fatimid protocol. ${ }^{58} \mathrm{He}$ also stresses in further occasions the jewelled nature of the parasol. ${ }^{59}$

In 1514, according to Ibn Iyās, the Mamluk Sultan Qānsūh al-Ghūrī (r. 1501-1516) replaced the bird that had traditionally topped the qubba or royal parasol with a gold crescent, the symbol of Islam. ${ }^{60}$ The importance of this passage is twofold: first, it confirms that the term qubba was used to indicate the parasol as well; second, it provides us with the date until which the parasol's finial was still bird-shaped.

Sanders 1994, 88-90.

55 Sanders 1994, 88-90.

56 El-Toudy - Abdelhamid eds. 2017, 239 (emphasis added). As already mentioned, to the state of our knowledge such a heritage from the Fatimids is not attested by written sources.

57 Holt 1993, 192

58 He reports in particular about the sultan of Maqashaw (Mogadishu; see Gibb ed. 1959, 377). Ibn Bațtūṭa guided a Moroccan embassy to the empire of Mali and describes the local Sultan holding audience seating under «a parasol, that is to say, something like a silken cupola [...] On top of it is a gold bird the size of a falcon» (see Gibb - Beckingham eds. 1994, 959). In Morocco, where the orientalist painter Eugène Delacroix (d. 1863) portrayed the ruler under a royal parasol (see Dakhlia 2005, fig. 1), still in the early 1980s high state awards counted a gold star plaque (to be worn over the shoulder from right to left) bearing on the second side «the representation of the royal parasol, red in colour» (Pellat 1995, 62).

59 Gibb ed. 1971, 651, 666, 712, 753, 760.

60 Alhamzah 2009, 41, 132. A crescent, hilāl-i rāyat, was already in use on top of the Ghaznavid banner's pennon (see Khan 1949, 81-83; Bosworth 1977, 99). 


\section{THE BIRD-SHAPED FINIAL AND ITS MEANING}

Numerous evidences, coming from cultural contexts earlier than the Islamic period, show parasols provided with a vegetal or geometric finial or without any finial. In the stone reliefs of Sargon II (r. 721-705 BCE) at Khorsabad the parasol is topped by a vegetal finial that can be identified with a lotus; in Persepolis' reliefs (in the Council Hall, the palaces of Darius and Xerxes, in Xerxes Haram) a fruit resembling a pomegranate probably with a good wishing role tops the parasol. ${ }^{61}$ It was a symbol of fertility by virtue of its thousand red 'seeds', ${ }^{62}$ thus largely represented in royal contexts. ${ }^{63}$

The introduction of an ornithomorphic finial must have occurred in the Islamic period, but what led sovereigns to shift from a vegetal symbol to a zoomorphic one is still to be understood. Most reliable sources place the introduction of the bird-shaped finial under the Ghaznavids. ${ }^{64}$ As far as we know, there is no coeval evidence from Egypt. References to this kind of finial date back to a later period when, according to the opinion of alQalqashandī, it was possibly adopted imitating a Fatimid prototype. ${ }^{65}$

It is not easy to infer the bird species from miniatures, but whenever the historical sources are specific in this regard, a falcon is mentioned. Taming falcons for hunting was regarded among the divertissements worthy of a king, as attested also in the Shähnama; ${ }^{66}$ but the symbolic meaning of such practise goes far beyond the pleasures of court. As written sources such as the Avesta (sacred Zoroastrian hymns) and the Bundahishn (the Book of Primal Creation, a Middle Persian encyclopaedic text) attest, in the Zoroastrian understanding of good and evil the falcon was a heavenly creation, entitled to hunt down and eliminate the evil creatures. ${ }^{67}$ The task of the (Persian) king was pretty much the same, so that martial arts and hunting skills had a similar role among the king's occupations. ${ }^{68}$ Moreover, since the falcon was associated with Verethraghna - the deity of offensive war and victory - ${ }^{69}$ and xwarrah - the heavenly fortune and glory,$-^{70}$ it became strictly linked to the Persian ideology of kingship. ${ }^{71}$ Even after the fall of the Sasanians and the decline of Zoroastrianism, the falcon enjoyed the position of royal companion in the framework of hunting. The Persian poet and mathematician 'Umar Khayyām, in his Nawrūznāma $\left(12^{\text {th }}\right.$

61 See Botta - Flandin 1849-1850, II, pls. 63, 71, 107, and in particular 113; and Schmidt 1953, pls. 75, 76, 138, $139,178-181,194$, respectively.

62 The finial could also be identified with the amalaka, a fruit employed as a finial on Hindu temples (see Rosser-Owen 1999, 28, fn. 2).

63 On the pomegranate in the ancient Near East, see Nigro - Spagnoli 2018.

64 The Turkish term lachïn for falcon was also adopted as a personal name, according to the Turkic custom. Bosworth $(1977,61)$ mentions the amir 'Aḍ̄id al-Dīn Lāchīn Khāzin as the addressee of a poem by 'Uthmān Muktārī.

65 Cf. above and fn. 56.

66 Daryaee - Malekzadeh 2018, 251.

67 Daryaee - Malekzadeh 2018, 245

68 Daryaee - Malekzadeh 2018, 247, 252

69 One of Verethraghna's avatars is a falcon, which possibly became a symbol of good luck on coins, crowns and seals (Daryaee - Malekzadeh 2018, 246)

70 The glory, xwarrah, is described flying to or away from kings as a falcon (Daryaee - Malekzadeh 2018, 246247).

71 The falcon connection with the Sasanian crown has already been pointed out (see above, fn. 14). 
century), stresses the «nobility and immaculacy» of falcons. ${ }^{72}$ In the Mantiq al-tayr (1177), a Persian mystical poem by Farīd al-Dīn 'Ațtāar, the falcon, fast and sharp-eyed, is described in an attitude full of dignity and conscious of its rank, since its distance from the common people entitles it to lay on the kings' shoulder. ${ }^{73}$ In the same way, as a symbol of royal archetype, the falcon is represented in front of Solomon - the king of the beasts - to symbolise the victorious heavenly kingdom just as lions beside him represent the terrestrial government. ${ }^{74}$ The term saqr ${ }^{75}$ falcon, thus seems to be a universal symbol of victory, linked by Tamari to the concepts of al- 'izz (the glory), al-sultān (the sultan), and al-nāsir (the victorious). ${ }^{76}$ "SSaqr Quraysh» is the nickname attributed to the Umayyad 'Abd alRaḥmān I (r. 756-788) by his rival the Abbasid caliph al-Manșūr (r. 754-775). ${ }^{7}$

The parasol finial is often referred to as a jewel, probably because of its shiny appearance, because it crowned a device already distinguished by prised fabrics, and maybe because of refined manufacture. It was likely made of metal, and in particular precious metals as suggested by al-Qalqashandī who writes of a «gold-plaited silver bird». ${ }^{78}$ Lastly, miniatures always show it as a golden finial. The presence of a pearl revealed by the Ghaznavid sources ${ }^{79}$ opens the chance that the bird was embellished by the addition of precious stones or inlay. The Persian traveller Nāșir-i Khusraw (d. 1088) reports that during the Nile procession of al-Mustanșir in 1047 the "parasol itself was covered with precious stones and pearls». ${ }^{80}$

Zoomorphic, often bird-shaped, finials are largely employed on Islamic metalwork especially on top of handles, lids and spouts, sometimes with an apotropaic role. Unfortunately, relating fragmentary preserved items to a specific artefact is all but easy. Furthermore, it is likely that once a parasol was damaged or deteriorated its finial was melt down. ${ }^{81}$ How the finials were fixed on top of the parasol can be tentatively inferred by observing the miniatures. Usually, the bird stands on a globular or spade-shaped pedestal. A couple of bronze artefacts might provide hypothetical examples similar to such finials. The first, ascribed to the $10^{\text {th }}$-century Iran, features a conical and flat-based pedestal; ${ }^{82}$ the second and far later one $\left(17^{\text {th }}-18^{\text {th }}\right.$ century) is inlaid with silver and presents a concave, sloping base possibly fitting a domed shape. ${ }^{83}$

Daryaee - Malekzadeh 2018, 254

Saccone 1999, 35-36, 48.

Tamari 1996, 99.

5 According to Ibn Hishām al-Lakhmī (12 $2^{\text {th }}$ century), the term saqr indicates any bird of prey employed in falconry, thus both eagles and falcons (see Martínez Enamorado 2011, 160-161).

76 Tamari (1996, 31 and fn. 46) recalls the role embodied by the falcon and the eagle as well for the Umayyad dynasty, both in Damascus and Cordova.

Tamari 1996, 113-114, fn. 68

See above and fn. 56

79 See above and fn. 13.

80 Cf. fn. 59

81 A pre-Islamic finial found at Gordion, approximately dated to the $8^{\text {th }}$ century BCE and attributed to a parasol, was wooden made (see Simpson 2014).

82 The artefact is mentioned by Allan (1976, II, 834, no. 4) and Rosen-Ayalon (1972, 180, fig. 33), who published the picture.

83 The item was auctioned: https://www.liveauctioneers.com/item/24665592 islamic-bronze-bird-finial-withsilver-inlay (last access: 19/06/2019). 


\section{CONTEXTS OF EMPLOY AND SOCIO-POLITICAL IMPLICATIONS}

The high number of miniatures and written sources including the parasol offer the chance to observe a wide range of situations and contexts this insignia was employed in. The parasol acted as a sign: it signalled the presence and position of the king on the field and distinguished his figure from the rest of his retinue, since the parasol was reserved to the king, not to his family members (with due exceptions). ${ }^{84}$ Beyond celebrative and military occasions, sometimes the parasol appears in funerary contexts. ${ }^{8}$

Miniatures show either historical kings or literary heroes shaded by the parasol, which always marks the prominent figure in the scene thus becoming an «expanded royal symbol» that embodies different values; such freedom of employ can be observed in late Islamic representations, while on ancient stone reliefs its role was much more restricted. ${ }^{86}$

The role of the parasol as a royal insignia deserves further analyses; in fact, the landscape should be enlarged to include other elements typical of the royal 'equipment' and regarded to embody the seat of the government: the palace, the tent and the throne. The relationship between them and the parasol is closer than it could seem.

As already stated, in the Fatimid context «the parasol clearly symbolised the palace». ${ }^{87}$ The expression al-qubba wa'l-tayr names the parasol, by virtue of its domed shape, through the term usually adopted for domed structures covering throne halls and entrance gates in Islamic civil architecture. Unfortunately, royal palaces built by the Ayyubbids and Mamluks in Cairo survive insufficiently; just few information are provided by the sources. ${ }^{88}$ Still, it can be assumed that the parasol was intended as a portable qubba on behalf of the actual qubba, the royal palace. The link between parasol and qubba is observed in miniatures on an iconographic ground through the addition of the falcon above both of them. Some of these miniatures show sloping domes on top of buildings. It could be hypothesised that they were made of fabric, as tents covering a terrace. ${ }^{89}$ In this case, the

84 Cf. fns. 9 and 36.

85 Parasols, like standards, were placed by the Seljuqs on the tomb of the deceased ruler as a mark of respect (see Andrews 1993, 193). Since the possession of the chatr corresponded to the possession of the throne, it accompanied the king even after his death. Ibn al-Athīr recounts about the succession of Berkyaruq (r. 10921105) that in 1104 the atabeg Ayaz brought back to Isfahan, along with the deceased sultan, «the sarāpardas (surādiqāt), tents (khiyām), royal parasol (chatr) and royal diadem (shamsa) and all that was required for a sultan and put it at the disposal of his son Malik-Shāh» (Durand-Guédy 2013, 168). Occasionally, the parasol was retaken to be used in the investiture of the successor ruler. It occurred in 1206, when a parasol was taken from a Ghurid tomb in Ghazni and carried to Firuzkuh (see Flood 2009, 122). See the parasol, topped by a bird-shaped finial, standing beside the dead Shīrīn in “The suicide of Shīrīn”, Niẓāmī’s Khamsa, Tabriz, 1505, Keir Collection (on loan with the Dallas Museum of Art), Ms. K.1.2014.739, cf. Canby 1999, 30, fig. 18. For a bird-shaped finial on a canopy in a funerary scene, see fn. 40 , in fine.

86 Sims 1992, 78. A miniature of a mid-15 ${ }^{\text {th }}$ century Shāhnāma from Iran (New York, Metropolitan Museum of Art, inv. no. 20.120.242, cf. MET website) displays Gav and Țalhand appearing inside canopies mounted on elephants and shadowed by domed-shaped parasols. The latter obviously serve no function, since the canopies have their own covers, if not marking the personages on the field.

87 Sanders 1994, 94. See above and fn. 44

88 O'Kane 2017, 587.

89 See Firdowsī’s Shāhnāma, Iran, 1446, London, British Library, Ms. Or 12688, fols. 130v (cf. Titley 1977, pl. 20 ), and 28v, 135r, 150v (BL website - images online); and a copy of Rashīd al-Dīn's Jāmi al-Tawārīkh Herat, 1430 ca., Bibliothèque nationale de France, Supplément persan 1113, fols. 28v, 130v, 135r and 150v (BnF website). 
link with the parasol would be even closer. A fabric-made tent would have covered the personage appearing inside a building as the parasol covers him outdoor. The falcon represents the trait d'union between the two devices.

A Safavid miniature consents to observe a morphological evolution: the parasol (without the bird-shaped finial) on a step forward toward the shape of an architectonic $q u b b a$ according to the shape in use under the Safavids (fig. 5). ${ }^{90}$

The term qubba could be used to indicate a dome-shaped tent as well. ${ }^{91}$ Thus, another conceptual link between royal devices is established. The tent is the absolute portable structure but also the closest one to the role of the royal palace, being the king residence and his audience hall. Some Muslim sultans are known to have preferred spending much of their time in nomadic tents. Seljuqs, for instance, were not sedentary rulers; even the longreigning Malik Shāh (r. 1072-1092), along with his activity as a patron of new buildings, lived also in tents (sarāparda). This custom consented to move from one place to another according to the change of seasons and to keep close relations with the army at any time, thus ensuring the power, and with the Turkmens as well. The value of the royal tent as the official seat of power was fully acknowledged. In the Seljuq court, the parasol is often associated to the tent - sometimes referred to as the red qubba - as a symbol of kingship. ${ }^{92}$

A further link between royal symbols concerns the parasol and the throne. The number of miniatures showing a falcon on top of the throne is revealing; some of them include it on both the throne and the parasol as the already mentioned miniature portraying the Ghaznavid Mahmmūd (fig. 1). Probably more numerous are the miniatures illustrating only the throne topped by a bird finial: among these it can be mentioned one from a Timurid manuscript of Rashīd al-Dīn's Jāmi 'al-Tawārīkh (Herat, 1430) showing the throne of the Mongol Chingis Khān surmounted by a falcon, thus attesting the persistence of the custom during the Timurid period (fig. 4). ${ }^{93}$

Finally, Maḥmūd al-Kāshgharī in his famous Dīwān lughāt al-turk (1072) provides the Khāqāni term for the parasol, chowāch, which interestingly denotes the crown - or the vault of heaven - as well. ${ }^{94}$ The domed shape - of either the qubba or parasol - ideally crowns the

90 Fig. 5 shows “Anūshīrvān and Buzurgmihr”, Nizāmī’s Khamsa, Khurasan, 1575, Boston, Museum of Fine Arts, inv. no. 14.594 .

91 Durand-Guédy 2013, 170-171.

92 For all these informations, see Durand-Guédy 2013, 172-180, 183.

93 "The proclamation of Chingis Khān", Paris, Bibliothèque nationale de France, Supplément persan 1113, fol $44 \mathrm{v}$, cf. Blochet 1929, pl. LX. For miniatures illustrating the throne with a bird finial, see Firdowsî's Shāhnāma, Iran, 1446, London, British Library, Ms. Or 12688, fols. 22r (Brend - Melville eds. 2010, ill. 4), 186r (Meri ed. 2006, front cover ill.), 19r, 37r, 45v, 84v and 197v (cf. BL website - images online); Jāmi 'alTawārīkh, Herat, 1430 ca., BnF, Supplément persan 1113, fols. 91r, 114v, 204 v (BnF website); "Giv brings Gurgin before Kay Khusrau", Firdowsī’s Shāhnāma, Iran, 1493-4, Washington DC, Arthur M. Sackler Gallery, Smithsonian Institution, Inv. no. S1986.160, cf. Canby 1999, fig. 4. A bronze beaker (Iran, dated to the early $1^{\text {st }}$ millennium BCE) shows a throne featuring an upward pointing protome in form of bird head (New York, Metropolitan Museum of Art, inv. no. 54.5; cf. Muscarella 1974, fig. 4). From the Elymaean complex in Tang-i Sarvak (eastern Khuzistan province, $1^{\text {st }}-3^{\text {rd }}$ centuries) comes a relief showing a bird-shaped footed throne (see von Gall 1971, fig. 1). These ancient prototypes may have influenced the choice of a birdshaped finial during the Islamic period.

94 Andrews 1993, 193 
king and reproduces the vault of heaven over his head. ${ }^{95}$ When such a device is carried above the king the latter is marked as an axis mundi between the Earth and the Sky, paralleling the order granted by the ruler to the cosmic one established by God.

\section{CONCLUSIVE REMARKS}

The fact that no reference to the use of the parasol in the Islamic context predates the Abbasid period might possibly indicate that such a device entered the Islamic royal protocol along with the introduction of Persian customs, given its ancient origin.

As demonstrated above, the parasol was a royal insignia: great attention was paid to the choice of its fabric, often a precious silk, its colour and decorative pattern, usually matching the caliph's robe. Nothing was left to chance in the Islamic royal protocol, and highly scenographic processions were common especially under the Fatimids.

The addition of a bird-shaped finial on top of the parasol helped enhancing its meaning and it must have been chosen carefully so to convey the right message. The falcon, whose first introduction can be historically retraced to the Ghaznavid period, enjoyed a royal connotation among the birds of prey. The varied contexts of employ indicate it as a flexible and inclusive symbol, proper to convey authority of the king as well as the role of the main character in the story. Evidence in Egypt point to the Mamluk period; still al-Qalqashandi believed that the al-qubba wa'l-tayr was a Fatimid heritage. ${ }^{96}$

The inclusion of the bird-shaped finial in so many miniatures attests its communicating strength and its historical persistence through centuries as a trace of the influence exerted by early Islamic rulers on the following dynasties. Miniatures' painters clearly drew from an iconographic repertoire that necessarily reflected the common awareness.

Since its employ in the crown that rested on the Sasanian kings' head, the bird of prey alluded to the concepts of glory and victory. The falcon added on top of the Islamic parasol retained the same meaning, being perceived as a mark of royalty enriching the insignia on a decorative as well as symbolic ground. ${ }^{97}$ The expression «in the service of the parasol (chatr) of the imperial stirrup», attested under the Seljuqs, equalises the parasol to kingship itself. $^{98}$ It demonstrates the physical transfer of authority and representativeness from the ruler to one of his insignia. ${ }^{99}$ In Flood's words, «as signs of sovereignty, inalienable objects often refer metonymically or synecdochically to the body politic [...] by the very act of possessing such sign, their possessor becomes what they embody». ${ }^{100}$

To conclude, a modern stone relief in Chashma 'Alī, near Rayy, where the Qajar Fath 'Alī Shāh (r. 1797-1834) appears in two scenes can be mentioned. In the first one, he is seated on his throne; in the second scene, on the right, he stands with a falcon on his

\footnotetext{
See Lehman 1945 (cf. Mathews 1982); Soper 1947; Smith 1950, in particular 81-83.

See above and fn. 56.

97 The Egyptian god Horus, who embodied the royal patron god, was also portrayed as a falcon (see Daryaee Malekzadeh 2018, 246)

98 Deny 1995, 529.

99 A similar phenomenon occurred during the aniconic period with regard to Buddha; see above fn. 3 .

100 Flood 2009, 122.
} 
forearm while an attendant holds a parasol behind him (fig. 6). ${ }^{101}$ The falcon, which used to top the parasol in earlier Islamic representations, comes back to its original function of hunter and its original position on the arm of the king. The intention of the two scenes seems to portray the king in his official duty and then in a more informal situation; still in the latter the parasol and the falcon are present, even if not together as in the traditional iconography analysed above.

\section{REFERENCES}

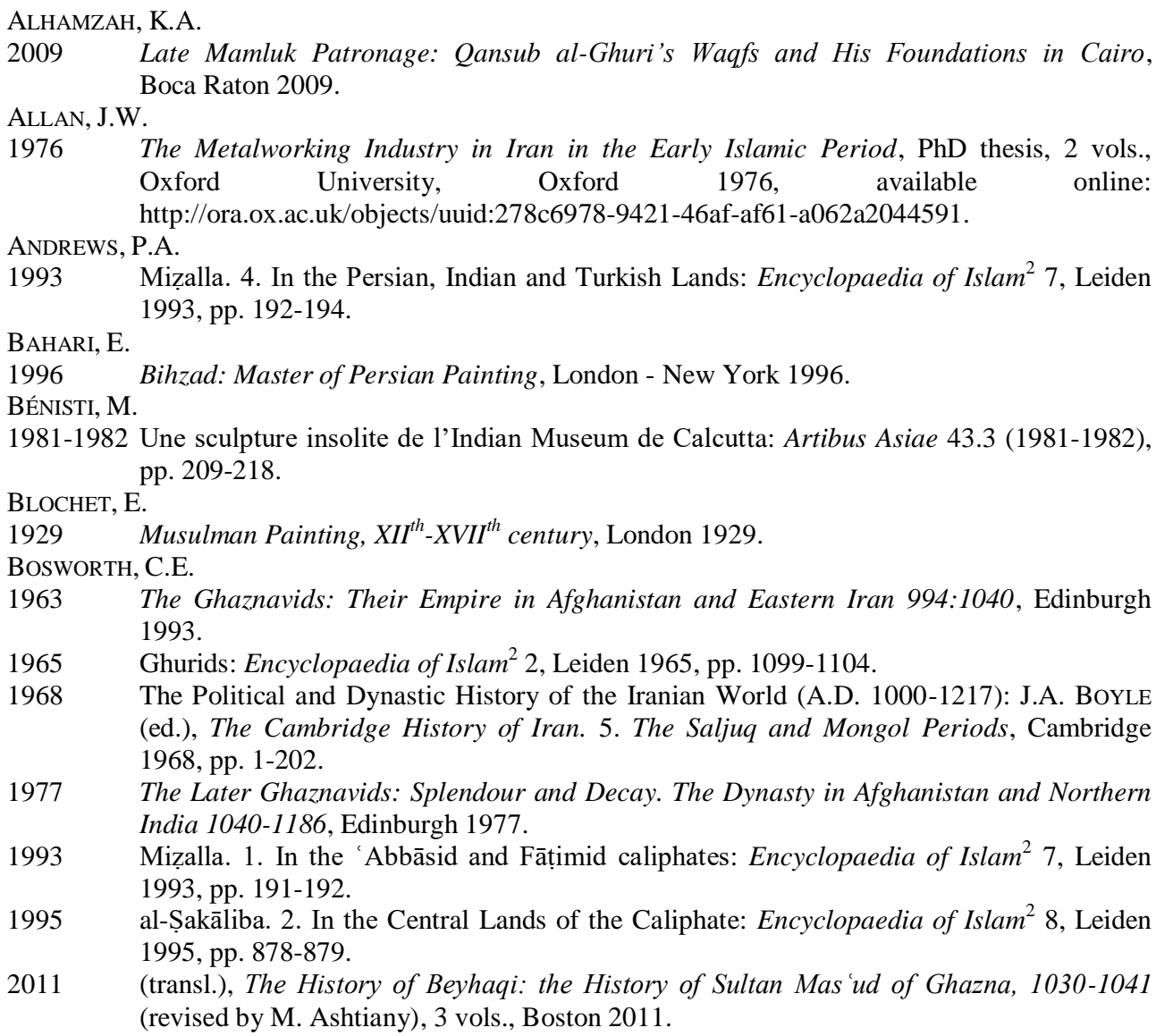

1965 Ghurids: Encyclopaedia of Islam ${ }^{2}$ 2, Leiden 1965, pp. 1099-1104.

1968 The Political and Dynastic History of the Iranian World (A.D. 1000-1217): J.A. BoYLE (ed.), The Cambridge History of Iran. 5. The Saljuq and Mongol Periods, Cambridge 1968, pp. 1-202.

1977 The Later Ghaznavids: Splendour and Decay. The Dynasty in Afghanistan and Northern India 1040-1186, Edinburgh 1977.

1993 Mizalla. 1. In the 'Abbāsid and Fāṭimid caliphates: Encyclopaedia of Islam ${ }^{2}$ 7, Leiden 1993, pp. 191-192.

1995 al-Ṣakāliba. 2. In the Central Lands of the Caliphate: Encyclopaedia of Islam ${ }^{2}$ 8, Leiden 1995, pp. 878-879.

2011 (transl.), The History of Beyhaqi: the History of Sultan Mas 'ud of Ghazna, 1030-1041 (revised by M. Ashtiany), 3 vols., Boston 2011.

101 The relief's photo by the photographer Antoin Sevruguin (d. 1933), glass negative numbered FSA A.4 2.12 GN.00.11, is available in Myron Bement Smith Collection, ca. 1910-1970 (Smithsonian Institution, Washington D.C.). https://learninglab.si.edu/resources/view/177753\#. See Luft 2001, 32-33. 
BotTA, P.E. - FlANDin, E.

1849-1850 Monument de Ninive, découvert et décrit par M.P.E. Botta, mesuré et dessiné par M.E. BOYLE, J.A. Flandin, 5 vols., Paris 1849-1850.

1968 Dynastic and Political History of the İl-Khāns: J.A. BoYLE (ed.), The Cambridge History of Iran. 5. The Saljuq and Mongol Periods, Cambridge 1968, pp. 303-421.

BRend, B. - Melville, Ch.P. (eds.)

2010 Epic of the Persian Kings: The Art of Ferdowsi's Shahnameh (Cambridge, The CANBY, SH.R. Fitzwilliam Museum, 11 September 2010 to 9 January 2011), London - New York 2010

1993 Persian Painting, London 1993.

1999 The Golden Age of Persian Art 1501-1722, London 1999.

Chalmeta, P.

1993 Mizalla. 3. In the Islamic West: Encyclopaedia of Islam 2 7, Leiden 1993, p. 192.

COOMARASWAMY, A.K.

1929 Les miniatures orientales de la collection Goloubew au Museum of Fine Arts de Boston (Ars Asiatica 13), Paris - Bruxelles 1929.

DAKHLIA, J.

2005 Pouvoir du parasol et pouvoir nu: un dépouillement islamique ? Le cas de la royauté marocaine: Bulletin du Centre de recherche du château de Versailles 2 (2005), available

DĀRĀB, GH.H. (transl.) on line: https://journals.openedition.org/crcv/233

1945 Makhzanol Asrār. The Treasury of Mysteries of Nezāmi of Ganjeh, London 1945.

DARYAEE, T. - MALEKZADEH, S.

2018 Falcons and falconry in pre-modern Persia: K.-H. GERSMANN - O. GRIMM (eds.), Raptor and human: falconry and bird symbolism throughout the millennia on a global scale, Wachholtz Verlag 2018, pp. 243-258.

DENY, J.

1995 Rikāb: Encyclopaedia of Islam² 8, Leiden 1995, pp. 528-529.

DURAND-GUÉDY, D.

2013 The Tents of the Saljuqs: D. DuRAND-GuÉDy (ed.), Turko-Mongol Rulers, Cities and City ERDMANN, K. Life, Leiden - Boston 2013, pp. 149-189.

1951 Die Entwicklung der sāsānidischen Krone: Ars Islamica 15/16 (1951), pp. 87-121.

FLOOD, F.B.

2009 Objects of Translation. Material Culture and Medieval "Hindu-Muslim" Encounter, Princeton - Oxford 2009.

Flood, F.B. - NeCIPOĞLU, G. (eds.)

2017 A Companion to Islamic Art and Architecture, 2 vols., Hoboken 2017.

FONTANA, M.V.

2012 The Meaning and the Iconographic Development of the Winged Sasanian Crown in the Early Islamic Art: L. KORN - A. HeIDENREICH (eds.), Beiträge zur Islamische Kunst und Archäologie, 3, Wiesbaden 2012, pp. 95-112.

FRIEDMANN, Y. (transl.)

1992 The History of al-Tabarī (Ta'rīkh al-rusul wa'l-mulūk). XII. The Battle of al-Qādisiyyah GALL, H. vON and the Conquest of Syria and Palestine, Albany 1992.

1971 Entwicklung und Gestalt des Thrones im Vorislamischen Iran: Archäologische Mitteilungen aus Iran 4 (1971), pp. 207-235. 


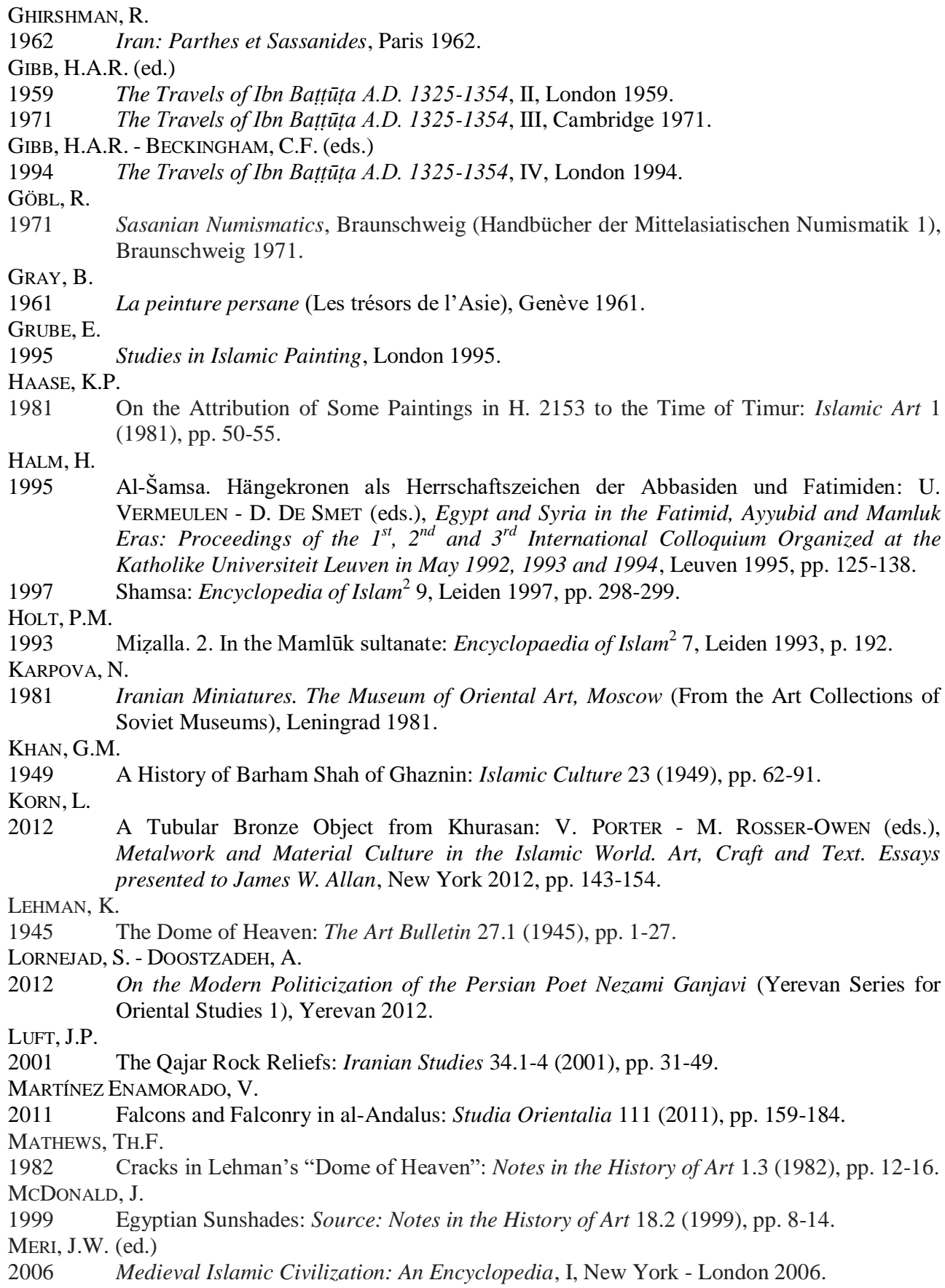

1949 A History of Barham Shah of Ghaznin: Islamic Culture 23 (1949), pp. 62-91.

KORN, L.

2012 A Tubular Bronze Object from Khurasan: V. PORTER - M. Rosser-OwEN (eds.), Metalwork and Material Culture in the Islamic World. Art, Craft and Text. Essays LEHMAN, K. presented to James W. Allan, New York 2012, pp. 143-154.

1945 The Dome of Heaven: The Art Bulletin 27.1 (1945), pp. 1-27.

LORNEJAD, S. - DOOSTZADEH, A.

2012 On the Modern Politicization of the Persian Poet Nezami Ganjavi (Yerevan Series for Oriental Studies 1), Yerevan 2012.

LUFT, J.P.

2001 The Qajar Rock Reliefs: Iranian Studies 34.1-4 (2001), pp. 31-49.

MARTÍNEZ ENAMORADO, V.

2011 Falcons and Falconry in al-Andalus: Studia Orientalia 111 (2011), pp. 159-184.

Mathews, Th.F.

1982 Cracks in Lehman's "Dome of Heaven": Notes in the History of Art 1.3 (1982), pp. 12-16. MCDONALD, J.

1999 Egyptian Sunshades: Source: Notes in the History of Art 18.2 (1999), pp. 8-14.

MERI, J.W. (ed.)

2006 Medieval Islamic Civilization: An Encyclopedia, I, New York - London 2006 
MILLER, M.C.

1992 The Parasol: An Oriental Status-Symbol in Late Archaic and Classical Athens: The Minissale, $\mathrm{G}$ Journal of Hellenistic Studies 112 (1992), pp. 91-105.

2000 Painting Awareness: A Study into the Use of Exotic Cultural Traditions by the Artists of the Emperor Akbar's Khamsa of Nizāmī, PhD thesis, SOAS - School of Oriental and African Studies, University of London, London 2000.

MONNERET DE VILLARD, U.

1968 Introduzione allo studio dell'archeologia islamica, Venezia - Roma 1968.

MusCARELla, O.W.

1974 Decorated Bronze Beakers from Iran: American Journal of Archaeology 78.3 (1974), pp. 239-254.

2013 Archaeology, Artifacts and Antiquities of the Ancient Near East: Sites, Cultures, and

NAFīsī, S.

1959 Divān-e qașāyid va ğazaliyyāt-e nezāmi ganjavi, Tehran 1959.

NigRo, L. - SPAGNOLI, F.

2018 Pomegranate (Punica Granatum L.) from Motya and its Deepest Oriental Roots: Vicino Oriente 22 (2018), pp. 49-90.

Novotny, J. - WATANABE, C.E.

2008 After the Fall of Babylon: A New Look at the Presentation Scene on Assurbanipal Relief: Iraq 70 (2008), pp. 105-125.

O'KANE, B.

2017 Architecture and Court Cultures of the Fourteenth Century: F.B. FLOOD - G. NeCIPOGLU (eds.) A Companion to Islamic Art and Architecture, Hoboken 2017, pp. 587-615.

Pellat, $\mathrm{CH}$.

1995 Nishān. 2. In the Maghrib: Enciclopaedia of Islam² 8, Leiden 1995, pp. 60-62.

RICHARDS, D.S. (transl.)

2016 The Chronicle of Ibn al-Athīr for the Crusading Period from al-Kāmil fî̀l-ta'rīkh. Part 1. The Years 491-541/1097-1146: The Coming of the Franks and the Muslim Response (Crusade Texts in Translation 13), Abingdon (Oxon) 2016.

RoSEN-AyALON, M.

1972 Four Iranian Bracelets Seen in the Light of Early Islamic Art: R. ETTINGHAUSEN (ed.), Islamic Art in the Metropolitan Museum of Art, New York 1972, pp. 169-186.

ROSSER-OWEN, M.

1999 A Córdoban Ivory Pyxis Lid in the Ashmolean Museum: Muqarnas 16 (1999), pp. 16-31. SACCONE, C.

1999 Farìd ad-Dìn 'Atțār. Il verbo degli uccelli, Milano 1999.

SANDERS, P.

1994 Ritual, Politics, and the City in Fatimid Cairo, New York 1994.

SCAGLIA, G.

1958 Central Asians on a Northern Ch'i Gate Shrine: Artibus Asiae 21.1 (1958), pp. 9-28.

SCHMIDT, E.F.

1953 Persepolis, I. Structures, Reliefs, Inscriptions (The University of Chicago Oriental SHAFI, I.M. Institute Publications 68), Chicago 1953.

1938 Fresh Light on the Ghaznavids: Islamic Culture 12 (1938), pp. 189-234. 
SIMPSON, E.

2014 A Parasol from Tumulus P at Gordion: A. ENGIN - B. HeLwiNG - B. UysAl (eds.), Studies in Honor of Engin Özgen, Ankara 2014, pp. 237-246.

SIMS, E.

1992 Čatr: Encycopcedia Iranica V, Costa Mesa 1992, pp. 77-79.

Sims, E. - MARShaK, B.I. - GRUBE, E.J.

2002 Peerless Images: Persian Painting and Its Sources, New Haven - London 2002.

SMITH, E.B.

1950 The Dome. A Study in the History of Ideas (Princeton Monographs in Art and Archaeology 25), Princeton 1950.

SOPER, A.C

1947 The "Dome of Heaven" in Asia: The Art Bulletin 29.4 (1947), pp. 225-248.

STCHOUKINE, I.

$1954 \quad$ Les peintures des manuscrits Tìmūrides, Paris 1954.

TAMARI, S.

1996 Iconotextual Studies in the Muslim Ideology of Umayyad Architecture and Urbanism, Wiesbaden - Ramat-Gan 1996.

TITLEY, N.M.

1977 Miniatures from Persian Manuscripts. Catalogue and Subject index of Paintings from Persia, India and Turkey in the British Library and the British Museum, Oxford 1977.

TOLAR, T.

2011 Images of a Seated Ruler in the Cappella Palatina - A Comparative Perspective on Art in Islam and Christianity, M.A. thesis, Central European University, Budapest 2011.

EL-TOUdy, H. - ABDELHAMID T.J. (eds.)

2017 Selections from Subh al-A shà by al-Qalqashandī, Clerk of the Mamluk Court, London New York 2017. 


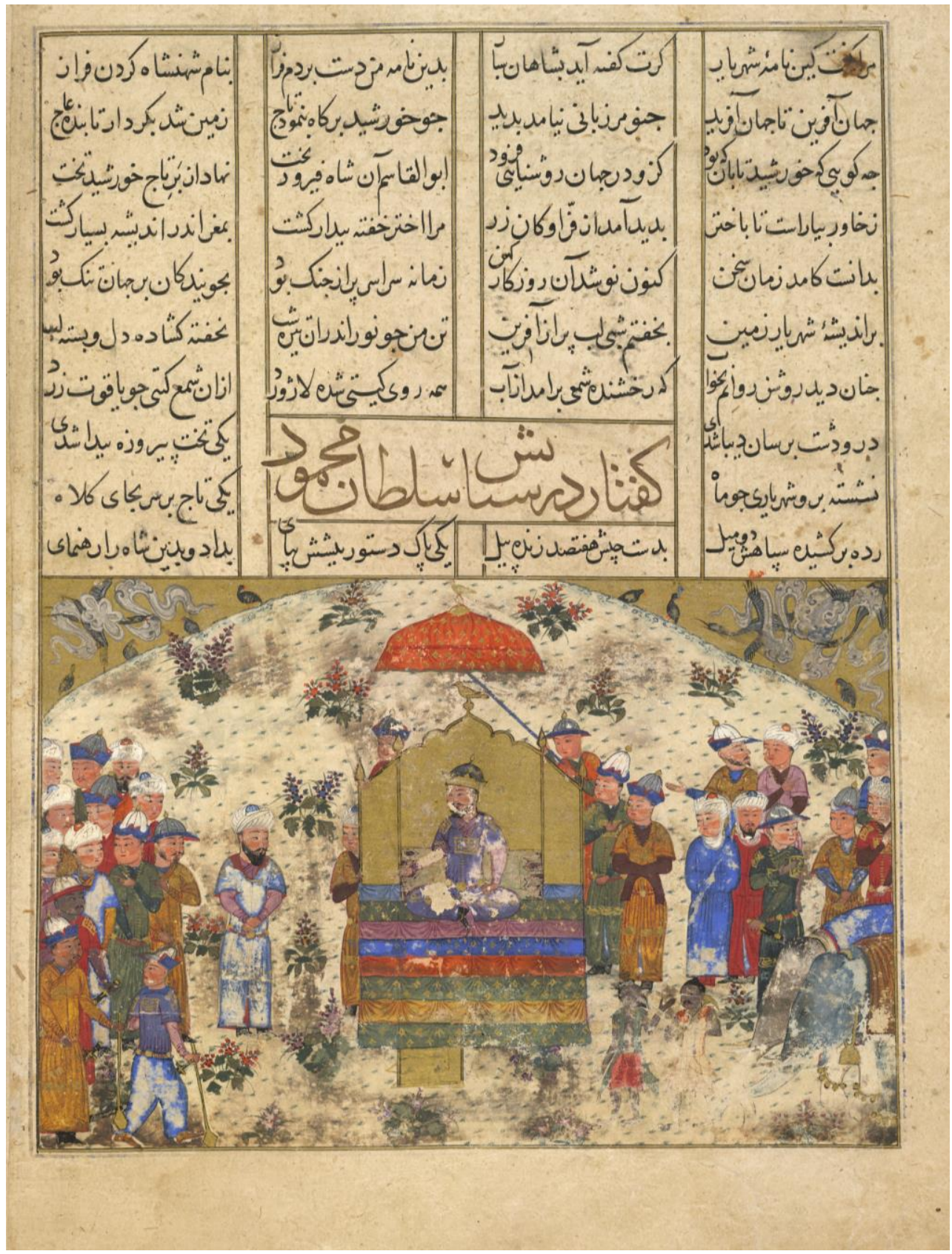

Fig. 1 - "The enthroned sultan Mahmūd of Ghazni”, Firdowsīs Shāhnāma, Iran, 1446, London, The British Library, Ms. Or. 12688, fol. 15v (courtesy of the British Library). 


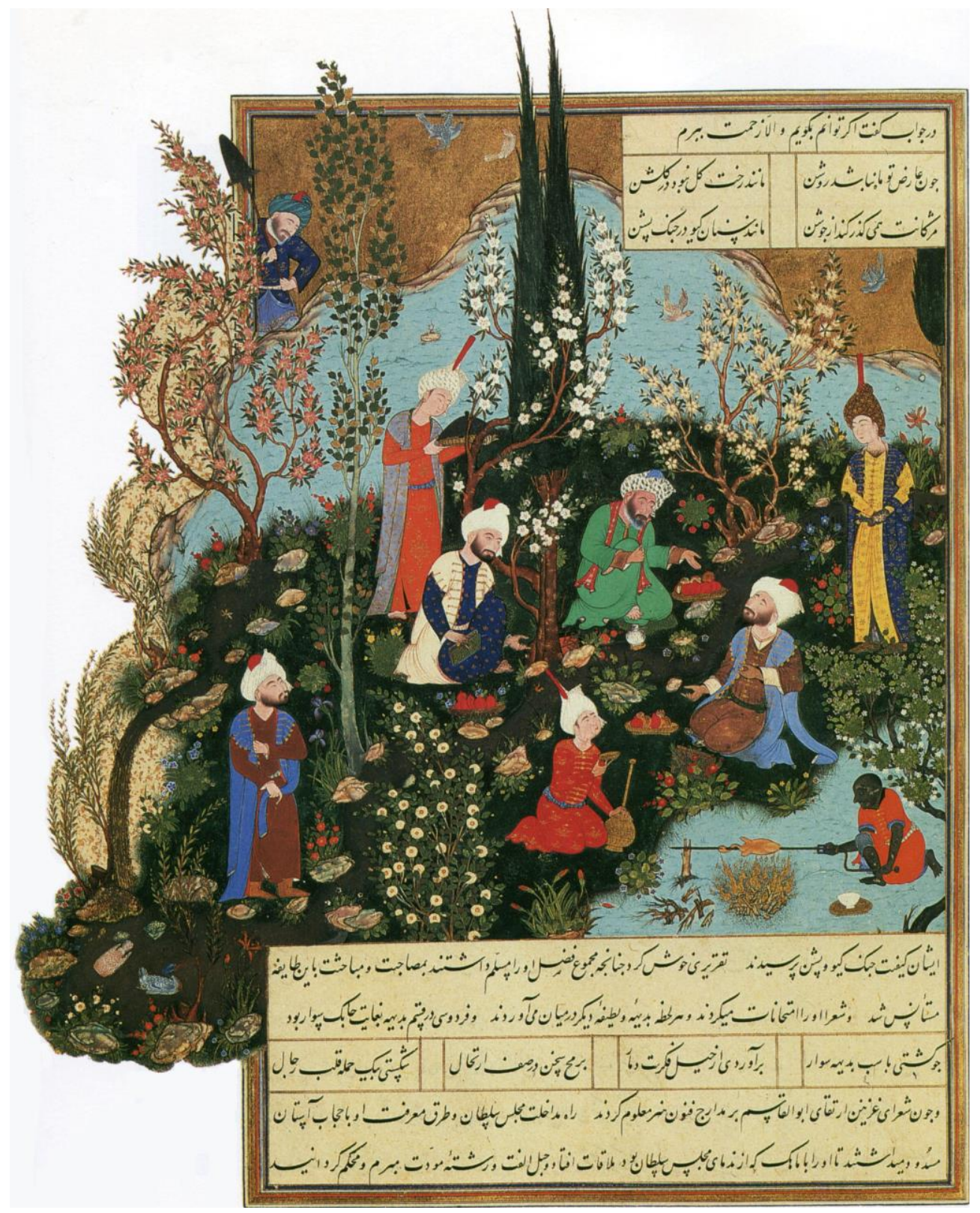

Fig. 2 - "Firdowsī meets the Ghaznavid court's poets 'Unșurī, Farrukhī and 'Asjudī", Firdows̄̄’s Shāhnāma, Iran, 1535, Toronto, Aga Khan Museum, Ms. AKM 156 (ex M185), fol. 7r (after Bahari 1996, fig. 117). 


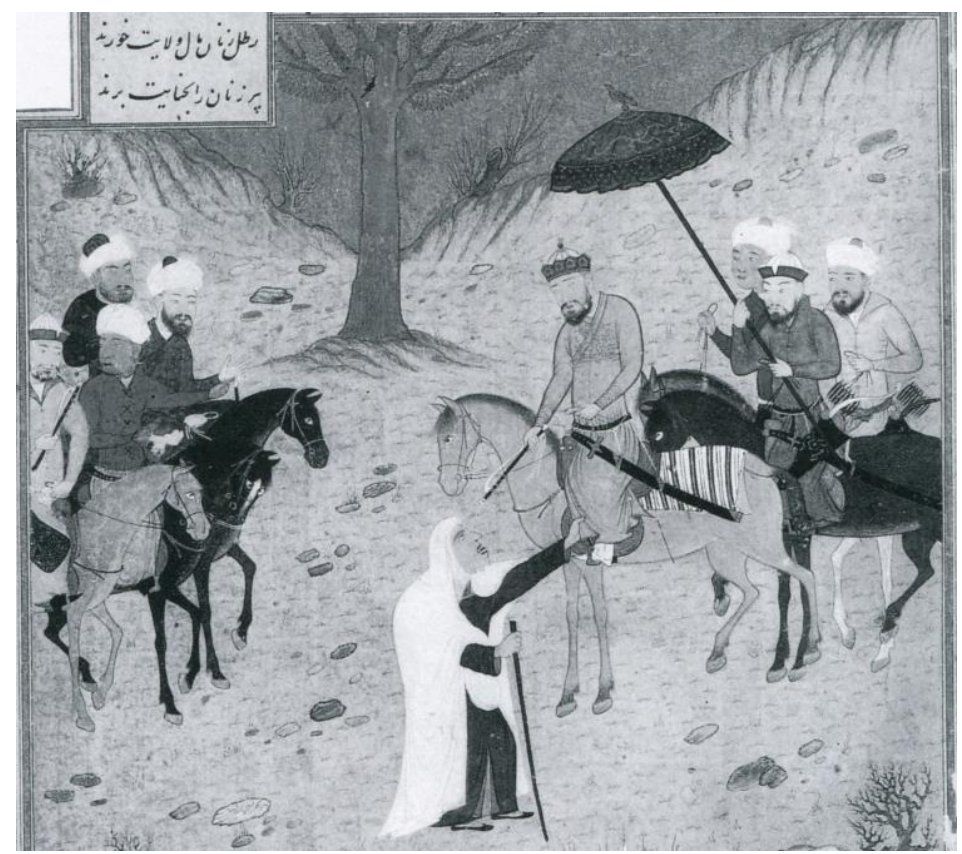

Fig. 3 - "Sultan Sanjar and the old woman", Nizāmī’s Khamsa, Herat, 1494-95, London, The British Library, Ms. Or. 6810, fol. 16r (after Bahari 1996, fig. 72, detail).

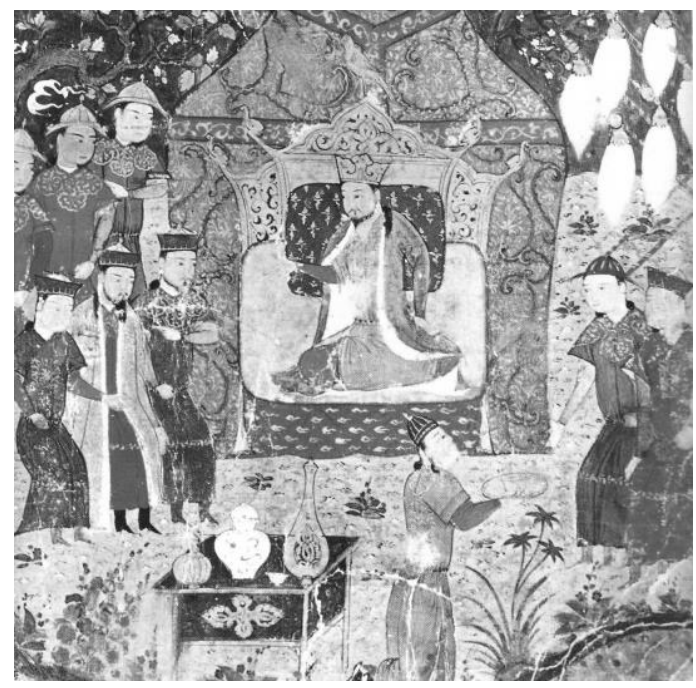

Fig. 4 - "The proclamation of Chingis Khān", Rashīd al-Dīn's Jāmi ' al-Tawārīkh, Herat, 1430, Paris, Bibliothèque nationale de France, Supplément persan 1113, fol. 44v, detail (after Blochet 1929, pl. LX). 


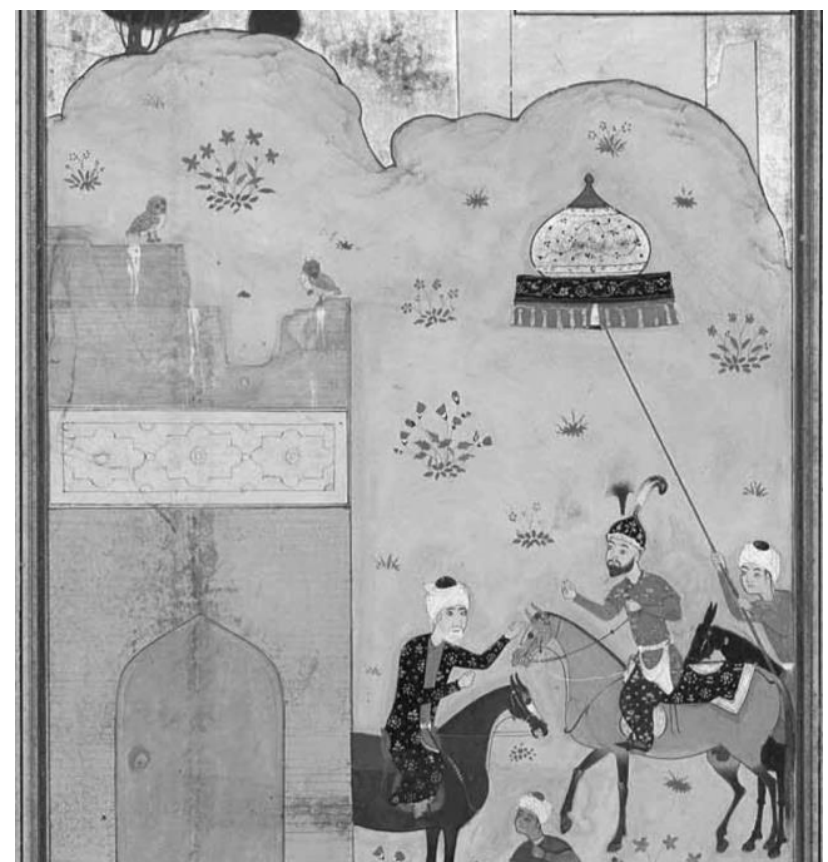

Fig. 5 - “Anūshīrvān and Buzurgmihr", Nizāāīs Khamsa, Khurasan, 1575, Boston, Museum of Fine Arts, inv. no. 14.594 (after Coomaraswamy 1929, pl. XL:70, detail).

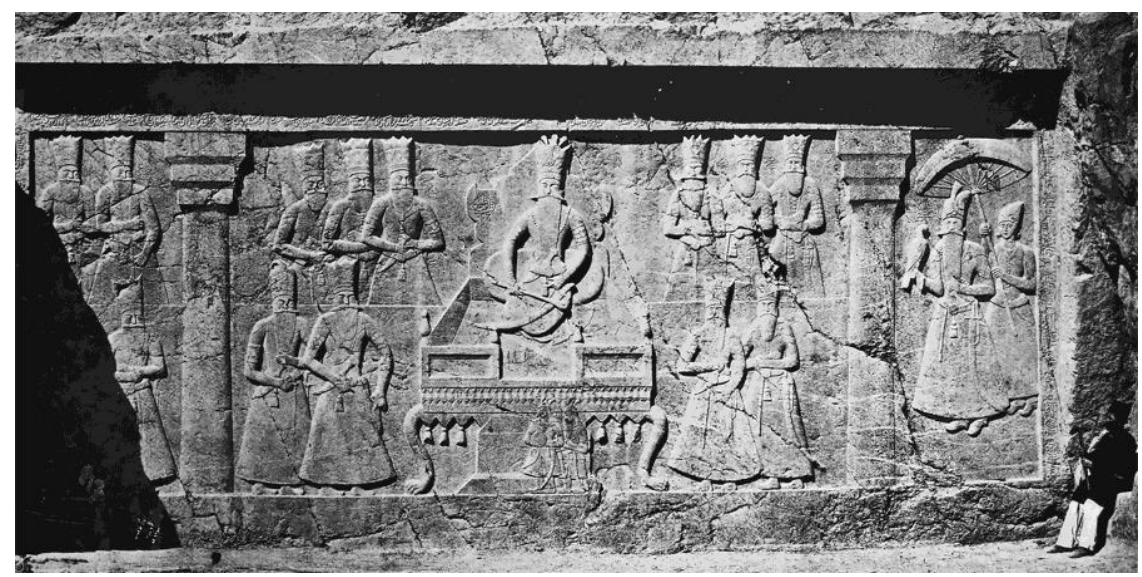

Fig. 6 - Stone relief in Chashma 'Alī, near Rayy, showing the Qajar Fath 'Alī Shāh (r. 1797-1834), photo FSA A.4 2.12 GN.00.11, M.B. Smith Collection, ca. 1910-1970 (Smithsonian Institution, Washington

D.C.) https://learninglab.si.edu/resources/view/177753\#. 